\title{
Aboriginal forestry joint ventures: Elements of an assessment framework
}

\author{
by Doug Brubacher ${ }^{1}$
}

\section{Forestry as a Cornerstone for the Emerging Aboriginal Economy}

Re-gaining control of their own economies has become a critical objective amongst First Nations across Canada, as they attempt to address major social and economic challenges, and build the foundations for Aboriginal self-government. As Aboriginal leaders search for the elements that will form their economic base, many are beginning to seek opportunities in the forest sector.

A recent report by Infometrica (1997) indicates that, according to the 1991 Census and Labour Force Survey, 10,000 Aboriginal people were employed in the logging and forestry industry. This represents $2.2 \%$ of total Aboriginal employment, and compares to a $0.8 \%$ participation rate in the forest sector amongst Canadians generally. Nonetheless, given the proximity of First Nations to the forest - $80 \%$ of Canada's 600 First Nations are located in productive forest areas (Royal Commission 1996) - a $2.2 \%$ level of employment in the forest industry is perhaps lower than might be expected. Historical roots for the low level of Aboriginal involvement in the forest sector can be found, both in the context of reserve forest management and in the relationship between Aboriginal communities and provincial Crown lands.

Under the Canadian Constitution, responsibility for Aboriginal affairs is held at the level of the federal government, while jurisdiction over natural resources has been assigned to the provinces. This has led to a situation in which large areas of Crown lands, much of which is considered by Aboriginal communities to constitute their traditional territories, have been leased to forest companies (Merkel et al. 1994). The Royal Proclamation of 1763, and the various treaties that have emerged since that time, address the rights of Aboriginal people to pursue certain activities in these regions. Nonetheless, over the past century, provinces have tended to shy away from the issue of Aboriginal and treaty rights, taking the position that these were federal responsibilities. The federal government, for its part, tended to avoid stepping into the issue of natural resource management as they pertain to Aboriginal peoples, deferring to the provincial mandate over these resources.

As Merkel et al. (1994) note, an outcome of this situation is that "As the forest industry and both provincial and federal governments prospered with the wealth generated by forests, Aboriginal communities grew poorer and more alienated from their traditional dependence on forest lands." A case study on the Lac Seul economy, commissioned by the Royal Commission On Aboriginal Peoples, notes that non-Aboriginal rules and regulations hold sway over traditional lands and resources. These are rooted in a world view so different from that of the Aboriginal perspective that "the result is cultural conflict and a retreat from economic activity" (Wien 1997).

\footnotetext{
${ }^{1}$ Consultant, community economic development, Aboriginal forestry policy and market research, 105 Caroline Avenue, Ottawa, ON, K1Y 0T1. E-mail: dbrubacher@cyberus.ca.
}

While Aboriginal people historically did not gain an active role in the development of the forest industry within their traditional lands off-reserve, neither did they manage to develop viable businesses and entrepreneurial experience based upon their on-reserve forest land base. On-reserve logging did occur; however, this was typically initiated under the stew-

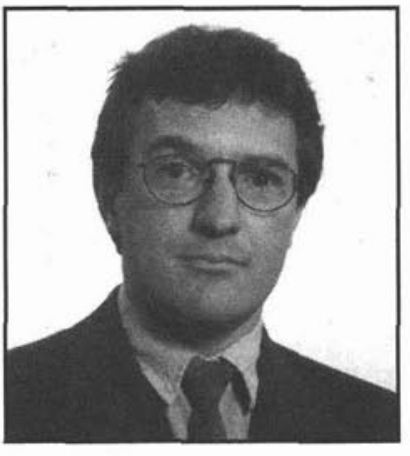
ardship of the Department of Indian Affairs and Northern Development (DIAND) which had jurisdictional responsibility for reserve lands. Logging contracts, often awarded to nonaboriginal logging companies, were managed by DIAND. Revenues flowed to the Bands' capital accounts which were administered by DIAND and used to pay for capital works in the communities, rather than being invested into building forestry capacity. A further factor limiting the contribution of on-reserve logging activities to developing Aboriginal capacity in the sector relates to the size of the reserve land base. In Canada, Indian Reserve Lands are simply too small to support the sort of profitable logging operations that have emerged in some reserves in the United States (the Menomonee, for example).

In recent decades the climate for Aboriginal involvement in the forest sector has begun to change. In its submission to the Royal Commission, the National Aboriginal Forestry Association (NAFA) noted the emergence of areas of common interest between Aboriginal communities and elements of non-Aboriginal Canadian society (NAFA 1993). These include growing public and judicial support for the recognition of Aboriginal and treaty rights, and the recognition of the need for sustainable approaches to development that consider the needs of future generations.

Nonetheless, from its historical beginnings, the forest industry has developed into a highly mechanized sector, with significant barriers to entry. These include: gaining access to the resource; high capital requirements; specialized human resource needs; and requirements for volume production capabilities to achieve break-even operation. Modern regulations also require ownership of processing facilities, such as sawmills or pulp mills, as prerequisites to obtaining timber harvest licenses. The high demands for capital and technological expertise required for these mills has been a major factor in putting participation in the industry beyond the reach of many Aboriginal communities (NAFA 1993). The recent Canada - US Softwood Lumber Agreement has added further barriers to entry of new interests by allocating tariff-free and tariff-reduced export quotas. While some quota was set aside for allocation to new entrants, most has been awarded on the basis of past export activity. For new entrants, the quota system has served as yet another barrier to entry into the sector. 
On their own, Aboriginal businesses and individuals are frequently limited in their capacity to overcome these barriers and respond to opportunities in the forest industry. These limitations may range from lack of capital, to limited entrepreneurial experience, poor community infrastructure, long-term effects of welfare dependency and human resource constraints (Wien 1997). With regard to this latter dimension, a report by the Aboriginal Forestry Training and Employment Review Committee concluded that the ability of Aboriginal people to take advantage of what is seen as "an immense opportunity and demand for Aboriginal employees in most aspects of the forest sector" has been limited by the lack of trained Aboriginal resource managers (IAS Committee 1997).

In spite of the present low rate of participation in the forest sector, and the significant barriers to entry into the sector, the forest industry is an area of significant potential for Aboriginal economic development. Forestry is seen by some to be the ticket forward for First Nations seeking to establish the economic base needed to support their communities into the next century. Working in their favour is the proximity of many Aboriginal communities to forests and the good "fit" of forest operations with the culture and knowledge base of many Aboriginal people. A significant shift within the business community toward willingness to enter into business relationships with Aboriginal corporations has also occurred during this decade.

To overcome the challenges to entry into the forest sector, and to capitalize on the increasingly favourable climate for cooperation between Aboriginal communities and business, an increasing number of First Nations are entering into joint venture relationships with established forestry companies. These business relationships are seen to provide a vehicle by which Aboriginal communities can build business capacity and develop their economic base (Lewis 1996). Through joint venture arrangements, Aboriginal companies - typically held by Band-owned economic development corporations - can gain entry into the local resource sector, utilizing the knowledge, experience and market positioning of a strategic partner.

A classic example of this approach has been well-documented by the former Economic Council of Canada in its case study of the Kitsaki Development Corporation. This corporation is owned by the La Ronge Indian Band, but operates at arm's length from this political entity. The joint venture companies it has created allows the Band to enter into a wide range of business sectors, ranging from regional transportation; life insurance; and food processing and marketing (Decter and Kowall 1993).

More recently, the Cree of Waswanipi, Quebec have entered into a joint venture milling company with Domtar Inc. The Waswanipi Band had for some time attempted to gain an active role in the forest sector. However, to access the capital required to initiate its involvement in the forest industry, the Cree needed access to a timber supply licence sufficient to supply the proposed mill. Before awarding such a license though, the province required a demonstration of sufficient expertise to undertake the management of the supply area.

The path out of this "Catch 22" situation was through a joint venture arrangement with an established company. Through the arrangement developed with Domtar Inc., a majority share of Nabakatuk Forest Products Inc. (55\%) is held by the Crees through the Mishtuk Corporation, with the remaining $45 \%$ share held by Domtar Inc. The resulting sawmill began operation in 1997 , and is based on timber supplied both from land controlled by the Waswanipi Crees and from the provincial timber supply licence area. Nabakatuk represents the first involvement of Quebec Crees as owners in a sawmill venture. The company developed out of a context in which logging and milling operations were expanding rapidly in the region, yet in which few Crees were benefitting from jobs in the sector (Quaile 1996).

\section{A Framework for Assessing Joint Ventures}

The growing importance of joint ventures in the portfolio of Aboriginal economic development strategies leads to considerable interest in analyzing these ventures in order to better understand their factors of success and failure. As with any partnership arrangement, the Aboriginal - Industry joint venture must be carefully designed to ensure that all partners stand to benefit from the arrangement. The process by which the joint venture is established must ensure that the venture partners understand these benefits and their limitations.

The remainder of this article presents a simple analytical framework that can begin to assist in assessing Aboriginal-Industry joint ventures. This approach addresses five areas of questioning toward each of the joint venture partners (Table 1). These include: the context in which the venture is developed; the objectives of the parties in entering into the arrangement; the accountability framework within which each partner functions; the contribution made by each partner to the venture; and, risks introduced by the partner to the venture.

Following a brief discussion of each of these areas of analysis, a specific joint venture company - West Chilcotin Forest Products of Anahim Lake, BC - will be assessed, using the framework as a guide.

\begin{tabular}{lcc}
\hline Table 1. Joint Venture Assessment Framework & \\
\hline Partner A & Partner & Partner B \\
& Context & \\
& Objectives & \\
& Accountability & \\
& Contribution \\
Risks & \\
\hline
\end{tabular}

\section{Context}

Assessing the context in which a joint venture business develops may involve examining both the social and economic situation of the partners involved in the venture, as well as that of other significant elements of the community or region who are not partners in the venture. Typical contextual issues that arise from the First Nation side may include social and economic indicators such as employment levels, demographic trends, human resource needs and the availability of training opportunities, community debate regarding appropriate use of the land, access to capital, and entrepreneurial capacity. Legal issues surrounding Aboriginal land claims and Aboriginal legal interest in the forest resource base are also of contextual significance.

Increasingly, forestry joint ventures are being negotiated in the context of locally high levels of unemployment amongst non-Aboriginal forestry workers. Global pressures leading to reduced employment levels within the industry, and other factors contributing to the state of non-Aboriginal community members should be recognized.

\section{Objectives}

The specific objectives of each party will depend on the context within which each partner finds itself. For the corporate 
partner, sustainable and predictable access to timber resources over the long term may frequently be high on the list of objectives. Developing workable models for cooperation with First Nation communities may be a further objective arising from a complexity of sources. These may range from developing a more favourable local context in which to operate, to improving public relations, to finding new allies in the forest.

Typically, private sector companies are concerned with operating in an efficient and cost-effective manner in order to improve competitiveness in the larger market and to generate profits within an appropriate time frame. These objectives may translate into concerns such as the need to move quickly into production to avoid the opportunity cost of tying up capital; maintaining good public relations in order to protect market share; and promoting a predictable policy and legal context in which to operate so that long-term investment strategies can be implemented.

The objectives of Aboriginal development corporations are typically focused on undertaking business activities in order to achieve multiple community objectives. These may include building equity through the establishment of solid, profitable businesses; creating local employment opportunities; generating revenues for community social and economic development; gaining a tangible role in regional resource utilization and management, and generating expertise amongst Band members in specific industry sectors or in business generally. These objectives, and those of private sector companies, can frequently be complimentary. The increasing emergence of joint venture businesses is testimony to this. Nonetheless, understanding the situation of each partner, and the expectations they have of the venture may be crucial to its success.

\section{Accountability}

An understanding of the accountabilities and constraints under which the partners operate when making decisions relevant to the venture will also be an important ingredient to the good functioning of the partnership. This is of particular relevance in the context of many Aboriginal business ventures carried out through Band-owned development corporations or their subsidiaries.

First Nations and industry have developed accountability mechanisms under quite different circumstances. The directors of private sector companies are accountable to company shareholders and to applicable law. This generally translates into concerns over the fiscal bottom line, although recently some corporations have begun to consider the "environmental bottom-line" as well. While First Nation-owned corporations are frequently established with accountability mechanisms designed to keep business decisions arm's-length from other community processes, these corporations frequently have social and development objectives as parts of their mandates. Thus, the directors of these corporations may be accountable not only to a fiscal bottom-line, but also to environmental, cultural and social "bottom-lines."

Informal accountabilities, arising from expectations of community members who may see themselves as "owners" in the corporation, may also exist alongside the formal structures. While Aboriginal development corporations may be structured to be at arm's length from the political entities in the community, they are often perceived by local politicians and other community members to be accountable to the community and to community objectives.

\section{Contributions}

Each partner contributes something to the venture. For the joint venture to successfully weather the challenges that will undoubtably arise, it is important that the significance and limitations of these contributions are recognized. Many firms recognize that retaining market share requires public recognition of good corporate citizenship. Experience, business savvy, and technical expertise are all contributions that can be critical to the success of a business. A ready and willing local labour force may also be a significant contribution. In addition to contributions of assets, capital, and access to the forest resource, parties may contribute in less tangible ways. "Social capital" may be contributed by partners who are able to bring with them the good will of their community.

\section{Risks}

In addition to the potential benefits that may arise, Aboriginal - Industry joint ventures also introduce new elements of risk to the business landscape. Each partner introduces their own dimensions of risk, and it is important that these risks are identified early on in the negotiation and design stages. Some risks may relate to inadequate understanding of the factors identified earlier. Misunderstanding the objectives or the accountabilities of the other partner may lead to difficulties, to the extent that these are not identified and mitigated. Other risks, such as additional time requirements introduced by a more complex decision-making structure, may be inherent to the venture itself and simply need to be anticipated and planned for.

\section{West Chilcotin Forest Products, Anahim Lake, BC}

The grid introduced earlier can be used as a convenient framework with which to analyze some of the key dimensions of the West Chilcotin joint venture arrangement (Table 2). The relevance of each of these dimensions of the joint venture is presented below, followed by a brief assessment of the venture experience for the partners involved.

West Chilcotin Forest Products (WCFP) is a joint venture milling company comprised of three partners: the Ulkatcho First Nation, CAT Resources Ltd. - a private company formed by a group investors from the community of Anahim Lake, and Carrier Lumber Ltd. of Prince George. The company began operation of its $\$ 3.5$ million sawmill operations in January, 1995, and its $\$ 1.5$ million planer mill in the summer of that year.

\section{Context}

The Ulkatcho First Nation is comprised of a small community of 750 people who live in and around the community of Anahim Lake. Beginning in the 1970 s, community leaders began lobbying the provincial government for a Forest License (FL). In the 1980s, the First Nation began to seriously do their homework by developing a forest management plan and formally applying to the government for a FL. With no previous experience in the forest sector, however, the province hesitated to award the licence, and the Ulkatcho First Nation's efforts failed to result in access to the forest for logging purposes.

Although some members of the Ulkatcho community did find employment with the Carrier Lumber company, these jobs were generally labour-type jobs. Opportunities for training and other support leading to higher level jobs were limited, as experienced crews were available to the company from outside the region. Frustration with the lack of contribution of the forest 
Table 2. Assessment Framework For West Chilcotin Forest Products

\begin{tabular}{|c|c|c|c|}
\hline Partner & $\begin{array}{l}\text { Ulkatcho First Nation } \\
\text { (Yun Ka Whu'ten Holdings Ltd.) }\end{array}$ & CAT Resources Ltd. & Carrier Lumber \\
\hline & $\begin{array}{l}\text { - owned by the First Nation through } \\
\text { its holding company } \\
\text { - holds a one-third share }\end{array}$ & $\begin{array}{l}\text { - a diverse group of investors from } \\
\text { the local community, formed for the } \\
\text { purpose of this venture } \\
\text { - holds a one-third share }\end{array}$ & $\begin{array}{l}\text { - the company that formerly ran } \\
\text { the mill and held the FL } \\
\text { - holds a one-third share }\end{array}$ \\
\hline Context & $\begin{array}{l}\text { - tried for years to gain access to the } \\
\text { forest for logging purposes } \\
\text { - initiated road blockades to protest } \\
\text { lack of access }\end{array}$ & $\begin{array}{l}\text { - formed following a community- } \\
\text { based land use planning process }\end{array}$ & $\begin{array}{l}\text { - lost its temporary timber license } \\
\text { in dispute with the province }\end{array}$ \\
\hline Objectives & $\begin{array}{l}\text { Jobs, training, community economic } \\
\text { development, participation in the } \\
\text { forest sector }\end{array}$ & Jobs, community cohesion & Timber supply \\
\hline Accountability & $\begin{array}{l}\text { Accountable to Band through Board } \\
\text { members appointed by the elected } \\
\text { Band }\end{array}$ & $\begin{array}{l}\text { Accountable to investors through } \\
\text { elected Board. Investors represent } \\
\text { a wide range of interests. }\end{array}$ & Accountable to private owners \\
\hline Contribution to the venture & Forest Licence & $\begin{array}{l}\text { Trust - "the deal-maker" that } \\
\text { convinced the province to award } \\
\text { the FL }\end{array}$ & Expertise, capital \\
\hline Risks introduced to the venture & $\begin{array}{l}\text { - the "unknown" } \\
\text { - would our cultural values be a risk } \\
\text { to the other partners? } \\
\text {-"politics often overrides business in } \\
\text { our communities" } \\
\text { - inexperience: First Nations have } \\
\text { mostly operated in a non-profit mode }\end{array}$ & - the "unknown" & - the "unknown" \\
\hline
\end{tabular}

sector to the community social and economic development, combined with concerns over long-term stewardship and land ownership issues grew. This came to a head in 1989/90, with civil disobedience leading to road blocks. Around the same time, environmental concerns relating to forest practices throughout the province were increasingly being raised.

In Anahim Lake, these converging factors led to a dispute between Carrier Lumber and the province that ultimately resulted in Carrier's temporary FL being suspended and the mill shutting down. With the closing of the Carrier mill, the nonnative community of Anahim Lake (population 400) lost a critical sector of its economic base. While much of the forestry operations at the time were carried out by out-of-town contractors, many Anahim families relied on Carrier for employment.

During this period of socio-economic crisis the "Anahim Round Table" process emerged as a forum in which divergent sectors of the community, including the residents of Anahim Lake, members of the Ulkatcho First Nation, environmental groups, as well as out-of-work loggers, could meet to "hash out their needs and interests in the land and resource base" (Birchwater 1995). With funding assistance from the provincial government, this twoyear process contributed to the development of a consensusbased community land-use planning document. This was the first and only such consensus document that emerged out of Round Table program in British Columbia, and it continues to be used for land use planning in the Anahim Lake region.

\section{The partners}

West Chilcotin Forest Products emerged as a joint venture company comprised equally of three partners. The Ulkatcho First Nation owns its one-third share in the company through Yun Ka Whu'ten Holdings Ltd., a company wholly owned by the Band and formed for the purposes of this venture. Carrier
Lumber holds another one-third stake in the company and sold the existing mills to the joint venture company.

The third partner, CAT Resources, is an investment group comprised of members of Anahim Lake, that was formed for the purposes of this venture. This eclectic group of 45 shareholders from the community of Anahim Lake provided the missing link needed to gain access to the timber supply required by the mill. "Among CAT Resources members there's probably a lot of people who were against logging five years ago, who are now shareholders in a local business. It's brought the white and native communities together for the most part," suggests Stephen James, CAT shareholder and West Chilchotin manager.

With the community clearly on-side, and a joint venture agreement signed with CAT Resources, Carrier Lumber and the Ulkatcho firm, Yun Ka Whu'ten Holdings Ltd, the Ulkatcho First Nation was able to obtain a five-year FL in November, 1994 , providing access to $140,000 \mathrm{~m}^{3}$. Access to an additional $100,000 \mathrm{~m}^{3}$ of beetle-kill timber was provided a year and a half later. The West Chilcotin Forest Products began operations in January, 1995. From a combined Aboriginal and non-Aboriginal population of 1,150 people, the West Chilcotin operations provides direct and indirect employment for more than 100 people.

\section{Objectives}

The objectives of each of the three parties for entering the joint venture vary substantially, yet are sufficiently complimentary to allow for successful coexistence. The Ulkatcho First Nation entered the venture with clear community development objectives. These focused upon using the venture as an opportunity to gain entry into the forest industry in order to begin to build the economic base needed for its sustained future. The success of the business as a profitable venture is seen as the key 
objective. However, the expectations are clear that this business must contribute to both the social and economic objectives of the community. Participation in the forest sector is expected to provide jobs, training opportunities along with contributions to the community social development.

One clear objective of the investors of CAT Resources was the development of jobs for community members. A further objective, shared with the First Nation partner, encompasses the development of community cohesion following the confrontations of the late 1980s between various sectors of the community. Building solid working relationships with the community's Aboriginal neighbours is also a recognized objective of the group.

For Carrier Lumber, the main objective has been to gain access to the timber supply in order to maintain operations in the region, and to realize a return on the capital invested in the saw and planer mills.

\section{Accountability}

Carrier Lumber is a private company, whose directors are appointed by the owners. The directors of CAT Resources are elected from the shareholders, while the board of Yun Ka Whu'ten Holdings is comprised of directors appointed by the Band Council. In the Ulkatcho tradition, the Band Council is comprised of members appointed from within the community through a system based upon family representation.

Each of these three partners appoints two members to form the board of directors of West Chilcotin Forest Products. This equality of representation emerges from the ownership arrangement (one third for each partner) and extends through WCFP's board structure to all aspects of the company's activities, from harvest to silviculture to marketing decisions.

From the point of view of the First Nation directors, their accountability is first to the joint venture. However, there is further recognition of an accountability to inform the community about what is happening with the company, and accountability to ensure equal access to opportunities provided by the company. The directors also recognize their accountability to ensure that the business is sustainable over the long term, and they struggle to balance business decisions, the need to make profit at the end of the day, Ministry of Forests requirements, and First Nation rights and values. While not all of these are legal accountabilities, the past experience in the region has clearly shown that when business fails to address community needs and issues, political responses can develop as powerful - if rather divisive - forces for change.

\section{Contribution to the venture}

The key contributions brought by each partner to the venture are the FL, brought by the Ulkatcho First Nation, and the expertise and experience brought by Carrier Lumber. CAT Resources served to provide the show of support that was needed to convince the province to award the FL. With the support of diverse sectors of the community behind the joint venture, as represented by the broad base of CAT Resources' membership, the province received a clear message that the trust was there to carry the venture forward. In addition, this show of local support ensured that several options became available for the Ulkatcho First Nation to access the capital it required to purchase its share.

Other contributions include the supply of a highly motivated, local workforce. The joint venture agreement sets out that employment is to be divided equally between members of the Anahim Lake community and the Ulkatcho First Nation. This local work- force replaces the crews that previously were brought in from outside the region.

\section{Risks}

Several risks that may have been introduced to the joint venture are recognized from the point of view of First Nation participants in the venture. The first is the lack of experience in for-profit enterprises. Agencies and members of the Ulkatcho First Nation have generally had more experience functioning in not-for-profit contexts than in business situations. This inexperience has been offset, however, by a clear understanding on the part of the Ulkatcho partners that business considerations must come first, if any of the social and community development objectives are to be met. The equal position of a very experienced company, Carrier Lumber, helps to ensure that the relevant business expertise is brought to the table.

A second area of potential risk that is identified from within the First Nation side of the venture is the issue of local politics. As is perhaps the case with other small communities, political considerations have been seen to sometimes override business considerations in making decisions in this community. Two aspects of this joint venture help to reduce exposure to the risk of local political interference in business decisions. First, the tripartite organization of the company's board of directors ensures that no one partner can unilaterally override the others. Secondly, recognition of the potential risk represented by political interference has focused considerable vigilance on the part of Ulkatcho First Nation directors on the WCFP board to keep politics out of business. The accomplishment of this objective has been attributed in part to the solid political structure of the Band. With a strong mandate from the Band, and support from the community, managers have been allowed to do their jobs.

A final area of risk is that introduced by the innovative nature of this joint venture. The three equal partner arrangement combining First Nation, community and industry partners was the first of its kind in the region. As such, a measure of the "unknown" was introduced to the venture as a potential risk factor. While areas of differences have emerged within the partnership, these have been worked out within the existing management framework.

\section{Conclusion}

The West Chilcotin joint venture provides a good example of a First Nation gaining entry into the forest sector through cooperation with others who hold a stake in the resource. At the local community level, cooperation between the First Nation and the non-Aboriginal community of Anahim Lake with the Carrier Lumber company sent a strong signal to the provincial government that requests from this partnership should be taken seriously. This cooperation has led to people and cultures working together in the Anahim Lake region. This is in contrast to the divisions that had emerged from competing values for forest land utilization in the past - divisions that were not necessarily formed along cultural lines.

The West Chilcotin experience has been designed to keep politics out of business, in order to ensure that the venture has the best chance possible of remaining profitable. Amongst the lessons learned, is that in negotiating a joint venture arrangement, it is critical that the time is taken to reflect the diversity of values represented in the communities that are involved. 
Community values should be reflected in the joint venture arrangement, so that politics do not have to override the normal business management processes after the fact. The equal division of ownership of West Chilcotin Forest Products amongst the three venture partners has further contributed to ensuring that diverse values are balanced around the board table.

While WCFP is designed and run as a profitable forest company, considerable social benefits have resulted. In addition to the direct benefits of increased jobs and related economic activity, other equally significant benefits are noted. First among these is what has been described as an increase in community morale. Related perhaps to this has been a decline in crime and alcohol abuse and an increase in entrepreneurial spin-off activity. In addition to direct employment in the mills, new opportunities for forest-related contracting businesses have emerged for local Aboriginal and non-Aboriginal people. Indeed, the invisible line that tended to separate the Aboriginal and non-Aboriginal populations of Anahim Lake is no longer as distinct as it has been in the past.

This case has illustrated how, by working together at the grassroots level, First Nation communities and their non-Aboriginal neighbours can accomplish considerably more than might be attempted through confrontation. New risks may be introduced by having a broader array of partners, each bringing their own set of values and formal and informal lines of accountability. Still, these risks can be managed through careful joint venture negotiation and design. They are considerably less significant that the risks introduced by neglecting the concerns of significant segments of the regional population, whatever these may be.

\section{Acknowledgements}

The author wishes to thank Ms. Laurie Vaughan, President, Yun Ka Whu'ten Holdings Ltd., and Mr. Steven James, General Manager, West Chilcotin Forest Products Ltd., for their assistance.

\section{References}

Birchwater, S. 1995. Forest company ventures into new territory. In 24 Williams Lake Advocate, Wednesday July 12, 1995.

Decter, M. B. and Kowall, J.A. 1993. A Case Study of the Kitsaki Development Corporation. pp. 29-60 In Regional Development from the Bottom Up: Selected Papers of the Local Development Series, 1993. Centre for Community Enterprise/Westcoast Publications. Port Alberni, British Columbia.

Industrial Adjustment Services (IAS) Committee. 1997. Aboriginal Human Resource Development Needs in the Forest Sector: Phase III - Final Report. Prepared for the Aboriginal Forestry Training and Employment Review (AFTER) and the National Aboriginal Forestry Association (NAFA).

Informetrica. 1997. Employment prospects for Aboriginal youth in Canada. Prepared for Indian and Northern Affairs Canada. March, 1997. Lewis, M. 1996. Leverage from the land: Joint Ventures As A First Nation Community Economic Development Strategy. In Making Waves, Vol. 7, No. 4. Centre for Community Enterprise, Port Alberni, BC.

Merkel, G., F. Osendarp, and P. Smith. 1994. An analysis of the forest industry's views of Aboriginal participation. Prepared for the Royal Commission On Aboriginal Peoples.

NAFA. 1993. Aboriginal Forestry Training and Employment Review (AFTER) Phase I Final Report. Prepared for the AFTER Committee. February 1993.

NAFA. 1993. Forest land and resources for Aboriginal people: An intervention submitted to the Royal Commission on Aboriginal Peoples. Quaile, G. 1996. Crees and Trees: A position paper on the state of the forests in Eeyou Astchee. The Forestry Working Group of The Grand Council of the Crees/Cree Regional Authority. Ottawa.

Wien, F. 1997. Employment possibilities for Aboriginal people: A review of the research from the Royal Commission On Aboriginal Peoples. Dalhousie University. 